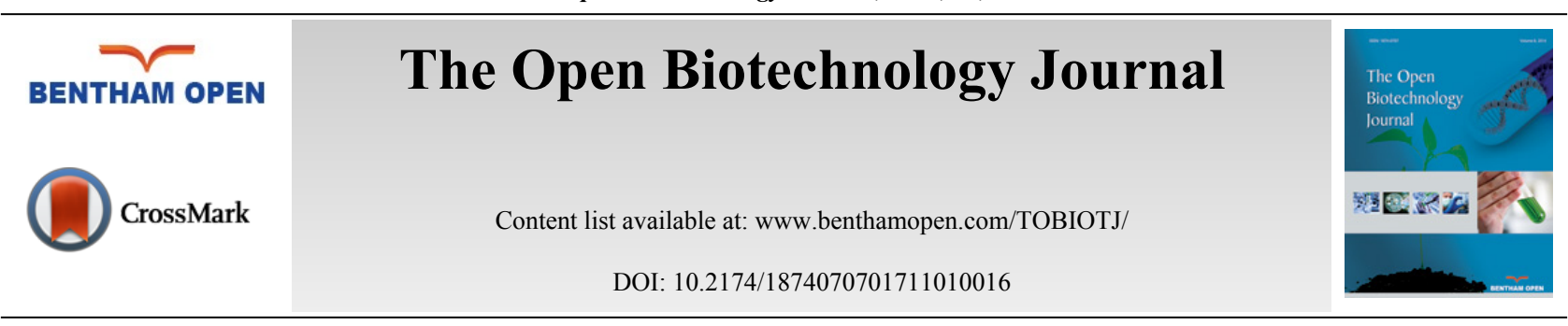

RESEARCH ARTICLE

\title{
Evaluation of Fixed-Bed Cultures with Immobilized Lactococcus Lactis ssp. Lactis on Different Scales
}

\author{
Rebecca Faschian ${ }^{\dagger}$, Ilyas Eren ${ }^{\dagger}$, Steven Minden ${ }^{\dagger}$ and Ralf Pörtner ${ }^{*}$ \\ Hamburg University of Technology, Institute of Bioprocess and Biosystems Engineering, Denickestr, Hamburg, \\ Germany
}

\begin{abstract}
Fixed-bed processes, where cells are immobilized within macroporous carriers, are a promising alternative to processes with suspended cells. A scale-up concept is presented in order to evaluate the performance as part of process design of fixed-bed processes. Therefore, Lactococcus lactis cultivation in chemostat and batch mode was compared to fixed bed cultures on three different scales, the smallest being the downscaled Multiferm with $10 \mathrm{~mL}$ fixed bed units, the second a $100 \mathrm{~mL}$ fixed-bed reactor and the third a pilot scale reactor with $1 \mathrm{~L}$ fixed bed volume. As expected, the volume specific lactate productivity of all cultivations was dependent on dilution rate. In suspension chemostat culture a maximum of $2.3 \mathrm{~g} \cdot \mathrm{L}^{-1} \cdot \mathrm{h}^{-1}$ was reached. Due to cell retention in the fixed-beds, productivity increased up to $8.29 \mathrm{~g} \cdot \mathrm{L}^{-1} \cdot \mathrm{h}^{-1}$ at a dilution rate of $\mathrm{D}=1.16 \mathrm{~h}^{-1}$ (corresponding to $2.4 \cdot \mu_{\max }$ ) on pilot scale. For all fixed bed cultures a common spline was obtained indicating a good scale-up performance.
\end{abstract}

Keywords: Fixed-bed reactor, Immobilization, Lactococcus lactis, Scale-up.

\section{INTRODUCTION}

Lactic acid bacteria (LAB) are commonly used in the production of fermented dairy products as well as for production of lactic acid, antimicrobial substances (bacteriocins) and biodegradable polymers, among others [1 - 3]. Industrial processes use mostly conventional batch or fed-batch fermentation with suspended cells. Reactor volumes go up to $100 \mathrm{~m}^{3}$, process time varies between several hours and days depending on the strain and the process strategy [2]. Even if high cell and product concentrations can be reached, the known drawbacks such as low productivity, product inhibition and also the variation from batch to batch remain [4 - 6].

Continuous cultivation of suspended cells is mainly performed with cell-recycle in perfusion mode to enable high cell concentration and product productivity [7]. For cell-recycle often filtration units have been applied (hollow fiber modules, ceramic membrane modules etc., reviewed in [7]). When used in long-term experiments, however, it is usually difficult to avoid membrane fouling due to cell growth. Furthermore, scale-up to industrially relevant scales has not been solved sufficiently yet.

Immobilization of LAB has many advantages compared to cell suspension culture such as high volumetric productivity, improved production efficiency and no possibility of washout [8-11]. Fixed-bed processes, where cells are immobilized within macroporous carriers, are very promising in this respect [7, $10-13]$. Immobilization of cells on inert porous carriers is an easy way to retain biomass [13 - 16]. Due to cell retention it is possible to run fixed-bed bioreactors in a perfusion mode at a steady-state with dilution rates higher than the maximum specific growth rate of the used strain. By this, very high volume specific productivity with respect to lactate can be reached and maintained for long periods of time. We recently reported on fixed-bed cultures of L. lactis, where the volume-specific lactic acid

\footnotetext{
${ }^{\dagger}$ these authors contributed equally to this work

* Address correspondence to this author at the Hamburg University of Technology, Institute of Bioprocess and Biosystems Engineering, Denickestr. 15, D-21073 Hamburg, Germany; Tel: +49 4042878 2886; Fax: +49 4042878 2909; E-mail: poertner@tuhh.de
} 
production rate was significantly higher as in batch culture, continuous cultivation could be maintained for approx. 50 days, and a successful scale-up to $1 \mathrm{~L}$-scale with perfusion rates of up to approx. $35 \mathrm{~L}$ per day [7].

Nevertheless, the number of industrial fixed-bed processes is quite small. To some extent this is due to the lack of process development tools for fixed-bed processes. To fill this gap, a strategy was developed for the design and evaluation of relevant process parameters of fixed-bed processes (Fig. 1). The first, very small scale of $10 \mathrm{~mL}$ working volume is the multi-fixed-bed bioreactor "Multiferm". We recently reported on the successful application of this system for the first evaluation of process parameters and kinetic modelling [17]. The next step is a $100 \mathrm{~mL}$ fixed-bed system, which can be operated continuously with reasonable effort to investigate the performance and long-term-stability of the culture. For small fixed-bed volumes with a height of approximately $10 \mathrm{~cm}$, the medium can be pumped axially through the bed. In this case the $\mathrm{pH}$ at the outlet should remain in a physiological range. A further increase of the length would result in too low $\mathrm{pH}$-values in the upper zones of the bed. This can be overcome by applying a radial medium flow, where the radius determines the length of the $\mathrm{pH}$ gradient, not the height of the column [7, 18]. As the first approach for scale-up, a $1 \mathrm{~L}$ fixed-bed reactor is applied. Even if this is probably not the final industrial scale, the reactor system already has the main characteristics of a large-scale system, mainly the radius. For further increase of the volume, just the height has to be increased [19].

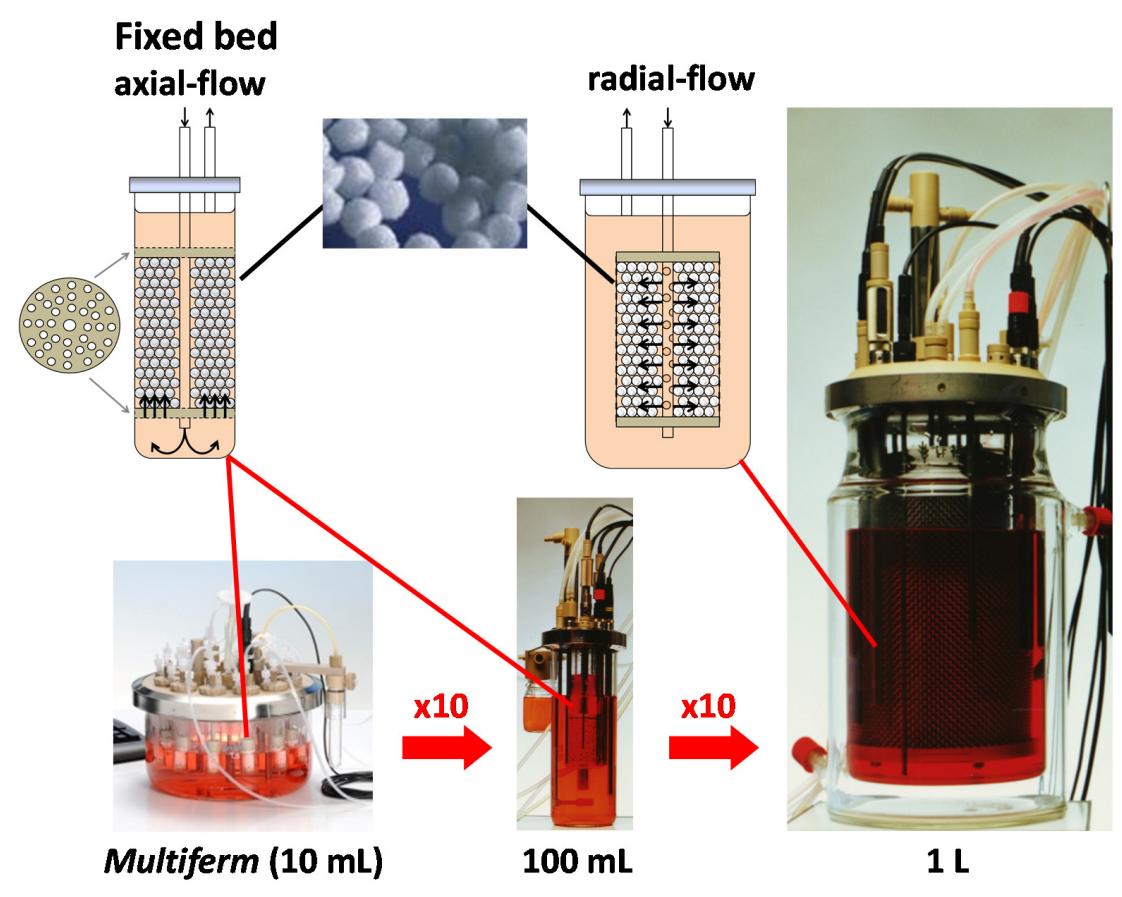

Fig. (1). Scale-up-concept for fixed-bed reactor systems (reactor systems: medorex e.K., Nörten-Hardenberg, Germany).

For all the three systems, a "proof-of-concept" has been shown before [7, 17]. The aim of the study presented here was to compare the performance of these three fixed-bed systems with Lactococcus lactis ssp. lactis regarding lactic acid production, biomass formation and lactose consumption. Furthermore, batch and chemostat cultures with suspended cells were performed to evaluate the productivity of the fixed-bed system.

In earlier studies of our group [7] the carrier CERAMTEC EO/90 gave promising results with respect to cell activity and long-term stability. But due to the form of the carrier (ring with inner diameter of $3 \mathrm{~mm}$, outer diameter of $8 \mathrm{~mm}$, height $8 \mathrm{~mm}$ ) the structure of the bed was non-homogeneous. Cells could not grow within the carriers due to the very low pore size (approx. $2.5 \mu \mathrm{m}$ ). Therefore, the risk for wash-out of cells was very high. Furthermore, the carrier had not been developed and optimized for biological applications. As an alternative a new, macroporous glass carrier $\left(V\right.$ itraPOR ${ }^{\circledR}$, ROBU $^{\circledR}$ Glasfilter-Geräte $\left.\mathrm{GmbH}\right)$, which had been developed especially for cell cultivation, was used here. 


\section{MATERIALS AND METHODS}

\section{Bacterial Strain}

For this study a Lactococcus lactis ssp. lactis strain (DSM-No. 20481 type strain, abbreviated as L. lactis) was used. It is a homofermentative strain that produces L-lactate under mesophilic growth conditions $\left(30{ }^{\circ} \mathrm{C}, \mathrm{pH} 7\right)$. Like many other lactic acid bacteria, it is anaerobic but aerotolerant. As standard medium M17 broth (Difco ${ }^{\mathrm{TM}}$, BD) was used, which was supplemented with lactose to a final concentration of $5 \mathrm{~g} \cdot \mathrm{L}^{-1}$. Medium and lactose solutions were autoclaved separately to avoid loss of substrate and nutrients due to Maillard's reaction.

\section{Suspension Culture}

\section{Inoculum Preparation}

For each experiment a fresh pre-culture was prepared from a cryostock as described previously [20]. This preculture was used as inoculum for experiments in the different reactors.

\section{Bioreactor Set-up for Batch Cultivation of Suspended Cells}

Batch cultivations with $\mathrm{pH}$ control were performed in the bioreactor system Vario 500 (medorex e.K., Germany), with a maximum working volume of $450 \mathrm{~mL}$. The double walled jacket was connected to a separate circulating water bath for temperature control. The axial propeller stirrer was driven at $300 \mathrm{rpm}$. The $\mathrm{pH}$ was controlled at $7.0 \pm 0.1 \mathrm{by}$ feeding of $5 \mathrm{M} \mathrm{NaOH} a q$ through a peristaltic pump coupled to an integrated $\mathrm{pH}$ electrode. Subsequently, the whole

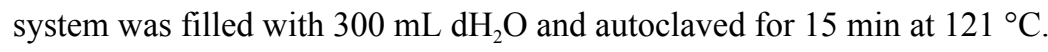

Before inoculating the fermenter with $1 \cdot 10^{8}$ cells $\cdot \mathrm{mL}^{-1}$, the $\mathrm{dH}_{2} \mathrm{O}$ was replaced by $360 \mathrm{~mL}$ medium and the bioreactor system was installed and ran overnight in order to let the medium reach the set temperature of $30{ }^{\circ} \mathrm{C}$ and to assess sterility. The next morning, a total of $4 \cdot 10^{10}$ cells from pre-culture were prepared in $20 \mathrm{~mL}$ fresh medium and inoculated with a Luer lock syringe. Subsequently, $20 \mathrm{~mL}$ of medium were then added to achieve the working volume of $400 \mathrm{~mL}$ and to wash cells from the inoculation pipe. Samples of $12 \mathrm{~mL}$ were taken every hour and assessed for biomass, lactate and lactose. Fermentations were performed three times.

Maximum specific growth rate was determined from the slope of the linear regression line of logarithmic plotted mean biomass data of these batch fermentations. This slope gave $\mu_{\max }=0.49 \mathrm{~h}^{-1}$. Equations are given in [20].

\section{Bioreactor Set-up for Continuous Chemostat Cultivation of Suspended Cells}

Chemostat experiments were carried out in the multi-fermentation system DASGIP ${ }^{\circledR}$ (Eppendorf AG, Germany). Experiments were performed under $\mathrm{pH}$ and temperature control to assess optimal growth conditions. Three reactor units with a working volume of $350 \mathrm{~mL}$ were run independently and in parallel. Each unit had an own medium reservoir from where medium at room temperature was fed through peristaltic pumps. Samples were withdrawn regularly for analyses of biomass, lactate and lactose courses. The dilution rates were chosen as $0.2,0.4,0.6,0.8$ and 0.9 times the maximum specific growth rate. For further details see [20].

\section{Fixed-bed Cultivation}

Cultivations of immobilized bacteria were carried out in fixed-bed bioreactors of different scales (Fig. 1), beginning with the multiple fixed-bed bioreactor system Multiferm, then in a $100 \mathrm{~mL}$-fixed-bed bioreactor and at last in a $1 \mathrm{~L}-$ fixed-bed bioreactor (all from medorex e. K, Nörten-Hardenberg, Germany).

\section{Multiferm Fixed-bed System}

The Multiferm comprises twelve single fixed-bed units consisting of a glass vessel, which is packed with the carrier material (10 mL, Fig. (1)). This bioreactor system was established and precisely described previously [17, 20]. Each unit was filled with borosilicate carriers (VitraPOR ${ }^{\circledR}, \mathrm{ROBU}^{\circledR}$ Glasfilter-Geräte $\mathrm{GmbH}$ ) with a mean diameter of 4 mm. The $\mathrm{pH}$ was not controlled. Temperature was controlled at $30^{\circ} \mathrm{C}$. The applied dilution rate was $0.5 \mathrm{~h}^{-1}$. Samples were taken at the outlet (harvest flow) of each fixed-bed unit.

For inoculation of the fixed-beds, a volume of $15 \mathrm{~mL}$ medium containing $10^{9}$ cells was transferred to every unit and 
incubated for $16 \mathrm{~h}$ overnight. The next morning the perfusion was started after a replacement of the exhausted medium. During continuous operation, samples were taken every $48 \mathrm{~h}$.

\section{0 mL-Fixed-bed Bioreactor}

The $100 \mathrm{~mL}$-fixed-bed bioreactor consists of two cylindrical glass vessels. The outer vessel $(1 \mathrm{~L})$ serves as heating chamber for the inner glass vessel, which is packed with the carrier material $(100 \mathrm{~mL}$, Fig. (1)). The principal set-up of the inner vessel is similar to the fixed-bed unit of the Multiferm (see above). For more details see [20]. Again, the borosilicate carrier (VitraPOR ${ }^{\circledR}, \mathrm{ROBU}^{\circledR}$ Glasfilter-Geräte $\mathrm{GmbH}$ ) with a mean diameter of $4 \mathrm{~mm}$ was used. The $\mathrm{pH}$ was not controlled. Temperature was controlled at $30{ }^{\circ} \mathrm{C}$ with a Pt100 sensor and a heating bath. A magnetic bar with a magnetic stirrer was used for mixing within the outer vessel. For continuous operation the fixed-bed bioreactor was connected to a storage tank with fresh medium and a harvest tank. Medium feed and harvest was done by peristaltic pumps. Samples were taken at the outlet (harvest flow).

For inoculation, $100 \mathrm{~mL}$ of a pre-culture were pumped into the empty bed. Cells settled within the fixed-bed during $16 \mathrm{~h}$ of incubation. Afterwards perfusion was started.

\section{L-Fixed-bed Bioreactor}

The 1 L-fixed-bed bioreactor consists of a 3.5 L double-walled glass vessel (Fig. 1). Into this vessel the wire-cage for the carrier bed (bed volume $1 \mathrm{~L}$ ) is integrated. Within the carrier bed, the circulating medium flows from an inner distribution tube parallel to the radius (radial flow). The radius corresponds to the height of the axial-flow fixed-bed bioreactors introduced above. For more details see [19]. Here the borosilicate carrier (VitraPOR ${ }^{\circledR}$, ROBU ${ }^{\circledR}$ GlasfilterGeräte $\mathrm{GmbH}$ ) with a mean diameter of $8 \mathrm{~mm}$ was used because the smaller size would fall through the mesh of the of the wire-cage. Additionally, the cultivations with the smaller carrier showed that channeling could occur after long cultivation periods due to strong cell growth. The $\mathrm{pH}$ was not controlled during continuous cultivation. Temperature was controlled at $30{ }^{\circ} \mathrm{C}$ with a Pt100 sensor and a heating bath. A magnetic bar with a magnetic stirrer was used for mixing within the vessel. For continuous operation the fixed-bed bioreactor was connected to a $355 \mathrm{~L}$ storage tank with fresh medium and a harvest tank. Medium feed and harvest was done by peristaltic pumps. Samples were taken at the outlet (harvest flow).

For inoculation $600 \mathrm{~mL}$ of a pre-culture were pumped into the empty bed. Cells settled within the fixed-bed during $18 \mathrm{~h}$ of incubation. After that perfusion was started.

\section{Analytics}

\section{Biomass}

Fermentation broth was analyzed on biomass content by measuring optical density at $600 \mathrm{~nm}\left(\mathrm{OD}_{600}\right)$. A previously determined correlation between OD and total cell concentration (TCC) was used to convert OD values to biomass content [20]:

$$
T C C=0 D_{600} \cdot 7.36 \cdot 10^{8} \quad \quad\left(\text { cells } \cdot \mathrm{mL}^{-1}\right)
$$

\section{Lactate and Lactose Concentration}

Substrate and product concentrations were determined by HPLC measurements with two devices as described previously [20] with the following parameters:

1. Cation exchange column (pre-warmed to $40{ }^{\circ} \mathrm{C}$ ), $2.5 \mathrm{mM}$ sulfuric acid as eluent, $0.3 \mathrm{~mL} \cdot \mathrm{min}^{-1}$, refractive index detector for both components.

2. Cation exchange column (pre-warmed to $50{ }^{\circ} \mathrm{C}$ ), refractive index detector for lactose, UV-detector for lactate.

\section{Cell Viability}

Cell viability was determined by fluorescence staining with acridine orange (AO) / propidium iodide (PI). The cell suspension was diluted with $0.9 \% \mathrm{NaCl}$, mixed with the staining solution (v/v $1: 1$ ), incubated for 2 minutes and then centrifuged at $3 \cdot 10^{4} \cdot g$ for 2 minutes. The supernatant was discarded, the cell pellet was resuspended in $0.9 \% \mathrm{NaCl}$ and centrifuged again. The supernatant was discarded, the cell pellet was resuspended in $0.9 \% \mathrm{NaCl}$. $10 \mu \mathrm{l}$ of this solution 
was filled into a microscope slide. Under a fluorescence microscope dead cells (red) and viable cells (green) were counted.

\section{RESULTS AND DISCUSSION}

\section{Relationship Between Maximal Growth Rate and pH}

In fixed-bed bioreactors a pH-gradient along the length of the bed is inherent to the system [7]. The radial flow geometry has been suggested to account for this effect. Nevertheless it is important to judge, if the pH-values at the outlet of the bed is still tolerable or unfavorable for the cells. An experimental series was performed to determine the relationship between the medium $\mathrm{pH}$ and the maximum specific growth rate $\mu_{\max }$ in shaking flasks without $\mathrm{pH}$ control. Fig. (2) illustrates the determined $\mu_{\max }$ values at different initial $\mathrm{pH}$ values. The values for $\mu_{\max }$ were determined from logarithmic plots of $\mathrm{OD}_{600}$ data from the exponential growth phase of shaking flask experiments with the indicated initial $\mathrm{pH}$ values. The presented data points are the means \pm SD of three independent experiments. The maximum $\mu_{\max }$ was scored at an initial $\mathrm{pH}$ of 6.9. Mild growth could still be observed at an initial medium $\mathrm{pH}$ as low as $\mathrm{pH} 5$ and as high as 8.8, whilst no growth was observed at a $\mathrm{pH}$ of 4.0 (data not shown).

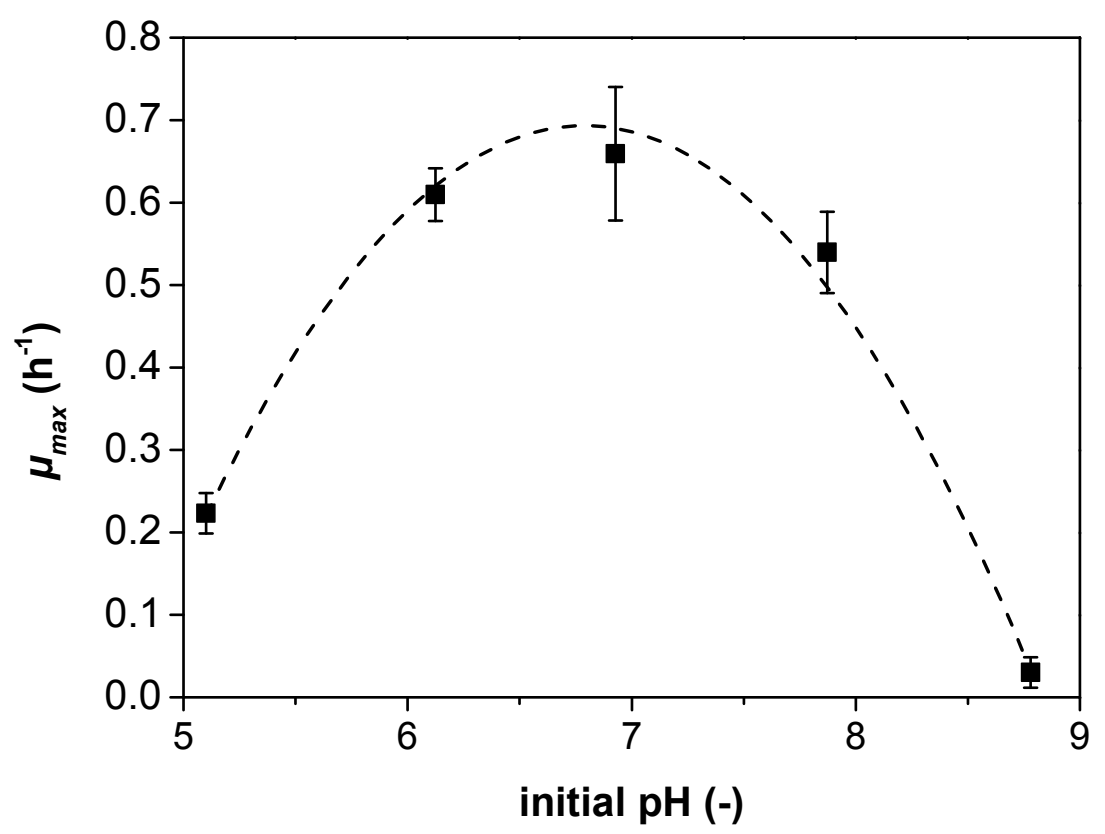

Fig. (2). Relationship between $\mathrm{pH}$ and maximal specific growth rate $\mu_{\max }$ for L. lactis grown in suspension.

\section{Fixed-bed Cultures on Different Scales}

Results obtained with the Multiferm system were already presented previously [20]. The volume specific lactate productivity as an indicator of the cell activity in the fixed-bed is highlighted here, as it was used as parameter to compare different reactor systems. At a constant dilution rate of $\mathrm{D}=0.5 \mathrm{~h}^{-1}$ the volume specific lactate productivity reached a mean steady-state value of $4.49 \mathrm{~g} \cdot \mathrm{L}^{-1} \cdot \mathrm{h}^{-1}$. Standard deviation from parallel runs was below $5 \%$, indicating a high reproducibility of the system.

Performance and long-term stability during a long-term cultivation in the $100 \mathrm{~mL}$-fixed-bed bioreactor were investigated by increasing the dilution rate step-wise (Fig. 3). After incubation of the inoculated cells for $16 \mathrm{~h}$ perfusion was started with $D=0.36 \mathrm{~h}^{-1}$ corresponding to $0.8 \cdot \mu_{\max }$ (time $0 \mathrm{~h}$ in Fig. (3)). The dilution rate was increased stepwise in intervals of approx. one day up to a dilution rate of $D=1.2 \mathrm{~h}^{-1}$, corresponding to $2.4 \cdot \mu_{\max }$. During the first $100 \mathrm{~h}$ the cell density in the harvest flow decreased, whilst the $\mathrm{pH}$ remained constant at 5.4. At this $\mathrm{pH}$ still a significant cell growth can be expected (compare Fig. (2)). Lactose was completely consumed for all dilution rates. Lactate concentration in the harvest flow was constant at $7.9 \mathrm{~g} \cdot \mathrm{L}^{-1}$ resulting in constant volume specific lactate production rates for dilution rates of $D=0.42 \mathrm{~h}^{-1}$ and $D=0.72 \mathrm{~h}^{-1}$. 


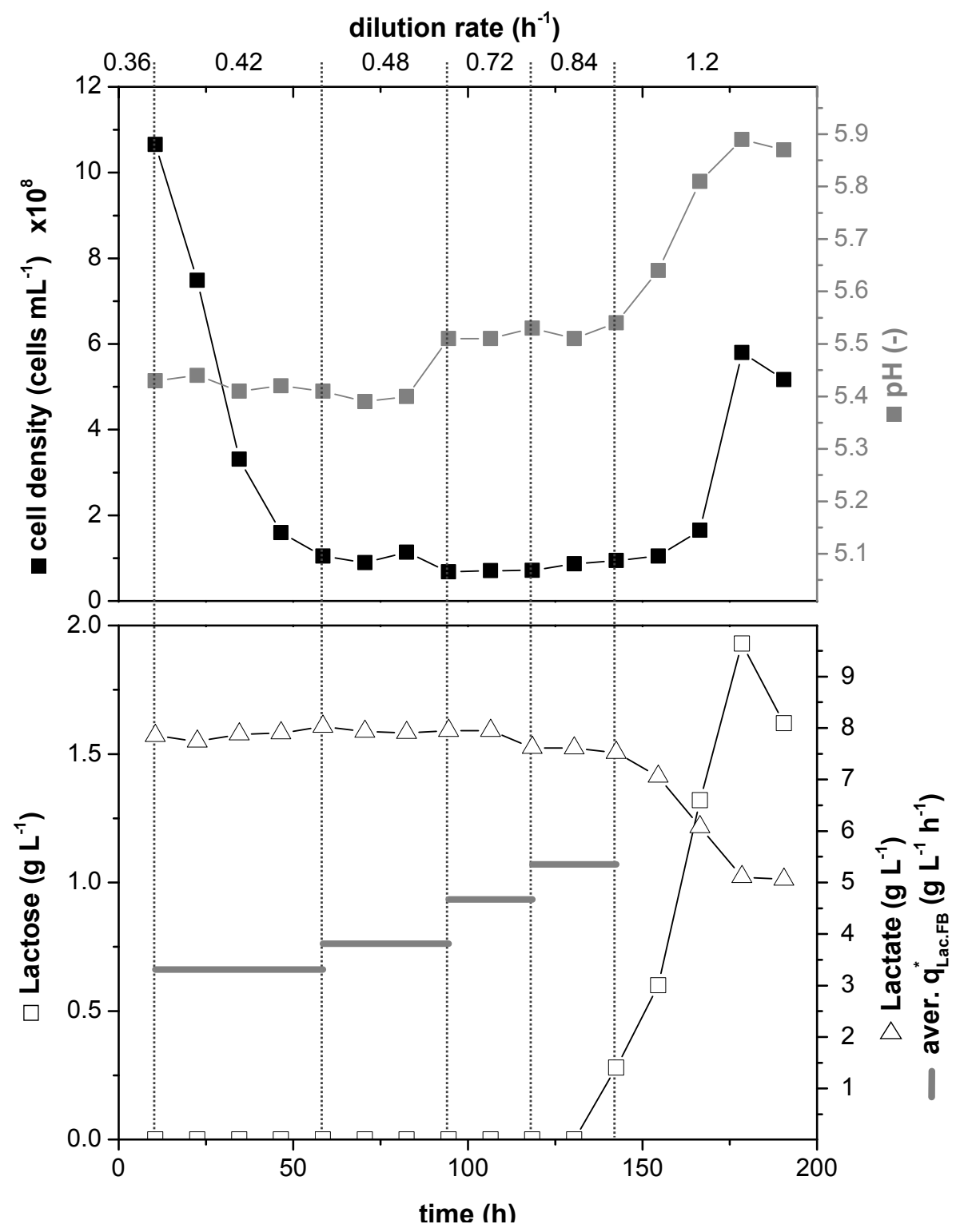

Fig. (3). Cultivation of L. lactis in the $100 \mathrm{~mL}$-fixed-bed bioreactor. Time course of cell density, pH, lactose and lactate concentration in harvest flow as well as average volume specific lactate production rate $\boldsymbol{q}^{*}{ }_{L a c, F B}$ in interval with fixed dilution rate. M17-Medium (Difco) with $5 \mathrm{~g} \mathrm{~L}^{-1}$ lactose, carrier: VitraPOR ${ }^{\circledR} 4 \mathrm{~mm}$.

When the dilution rate was further increased to $D=0.84 \mathrm{~h}^{-1}$ and $D=1.2 \mathrm{~h}^{-1}$, cell density, $\mathrm{pH}$ and lactose concentration in the harvest flow increased, lactate concentration and volume specific lactate productivity decreased. Obviously a wash-out of cells occurred. This effect was not expected at these low dilution rates, as in earlier fixed-bed cultivations with $L$. lactis steady-states could be maintained up to $D=4 \mathrm{~h}^{-1}$ [7]. In that case a larger carrier [CERAMTEC, see Introduction] and a different medium formulation was used. The different size of the carriers could be an explanation for the discrepancy. Fixed bed systems tend to become instable, if channels between the carriers become overgrown by cells resulting in diffusion gradients, e.g. for nutrients, metabolites or $\mathrm{pH}$. This effect is even pronounced for carriers with smaller diameters, as the width of the channels between the carriers is smaller in this case and can be blocked by growing cells. Similar effects have been observed for mammalian cells grown in fixed bed reactors [19]. It was decided to use a larger fraction of $8 \mathrm{~mm}$ mean diameter of the VitraPOR ${ }^{\circledR}$ carrier for the following experiment in the $1 \mathrm{~L}$-fixed-bed bioreactor for reasons mentioned in the material section.

The viability of the cells in the harvest flow remained around $85-93 \%$ during the whole cultivation (Fig. 4). This can be regarded as high, as similar values were found at the end of exponential growth phase in batch cultures (data not shown). 


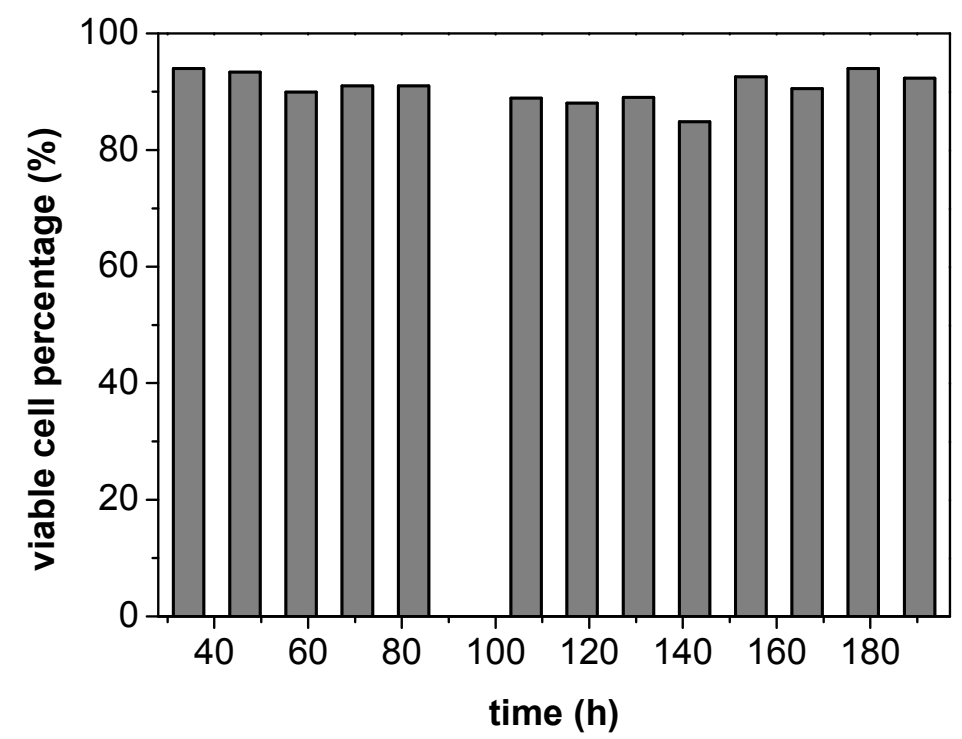

Fig. (4). Cultivation of L. lactis in the $100 \mathrm{~mL}$-fixed-bed bioreactor. Time course of cell viability. Note that there is a value missing between 80 and $100 \mathrm{~h}$.

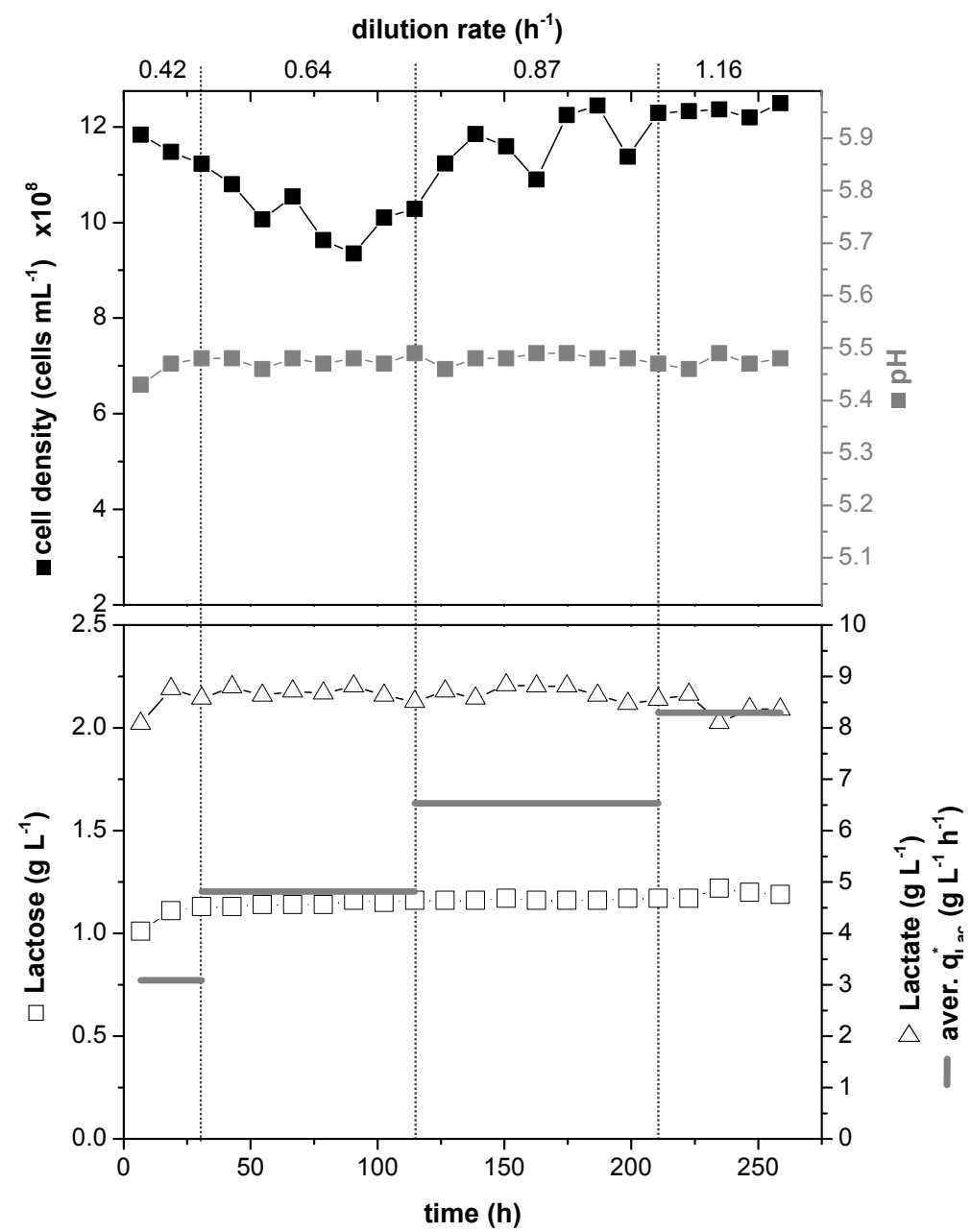

Fig. (5). Cultivation of L. lactis in the $1 \mathrm{~L}$-fixed-bed bioreactor. Time course of cell density, $\mathrm{pH}$, lactose and lactate concentration in harvest flow as well as average volume specific lactate production rate $\boldsymbol{q}_{\text {Lac,FB }}^{*}$ in interval with fixed dilution rate. M17-Medium (Difco) with $5 \mathrm{~g} \mathrm{~L}^{-1}$ lactose, carrier: VitraPOR ${ }^{\circledR} 8 \mathrm{~mm}$. 
Finally, performance and long-term stability in the 1 L-fixed-bed bioreactor were investigated by increasing the dilution rate step-wise (Fig. 5). After incubation of the inoculated cells for $18 \mathrm{~h}$ perfusion was started with $D=0.42 \mathrm{~h}^{-1}$ corresponding to $0.8 \cdot \mu_{\max }$ (time $0 \mathrm{~h}$ in Fig. (5)). The dilution rate was increased stepwise in intervals of approx. $3-4$ days up to a dilution rate of $D=1.16 \mathrm{~h}^{-1}$, corresponding to $2.4 \cdot \mu_{\max }$. The cell density in the harvest flow (approx. $10^{9}$ cells $\mathrm{mL}^{-1}$ ) and the $\mathrm{pH}$ (approx. 5.8) remained constant. At this $\mathrm{pH}$ a significant cell growth can still be expected (compare Fig. (2)). Lactose was not completely consumed, but remained constant at the different dilution rates (approx. $1 \mathrm{~g} \mathrm{~L}^{-1}$ ); lactate concentration in the harvest flow was constant (approx. $9 \mathrm{~g} \mathrm{~L}^{-1}$ ) as well, resulting in constant volume specific lactate production rates. The highest value $\left(8.3 \mathrm{~g} \mathrm{~L}^{-1} \mathrm{~h}^{-1}\right)$ was determined for $D=1.16 \mathrm{~h}^{-1}$. In contrast to the experiment in the $100 \mathrm{~mL}$-bioreactor (Fig. 3) the cultivation remained stable, probably due to the larger carrier size used here (as discussed above).

\section{Comparison of Suspension and Fixed-bed Systems on Different Scales}

For comparison of suspension and fixed-bed cultures the volume specific lactate productivity was plotted against the dilution rate (Fig. 6). For batch culture a value of $1 \mathrm{~g} \mathrm{~L}^{-1} \mathrm{~h}^{-1}$ was obtained. Continuous suspension cultures in chemostat mode showed the expected course [7]. At first the productivity increased with increasing dilution rate up to a maximum of $2.3 \mathrm{~g} \mathrm{~L}^{-1} \mathrm{~h}^{-1}$. When the dilution rate got close to the maximal specific growth rate $\mu_{\max }$, the productivity decreased, as wash-out of cells occurred. If dilution rates larger than the maximal specific growth rate are applied in chemostat cultures without cell retention, cells will be definitely to washed out.

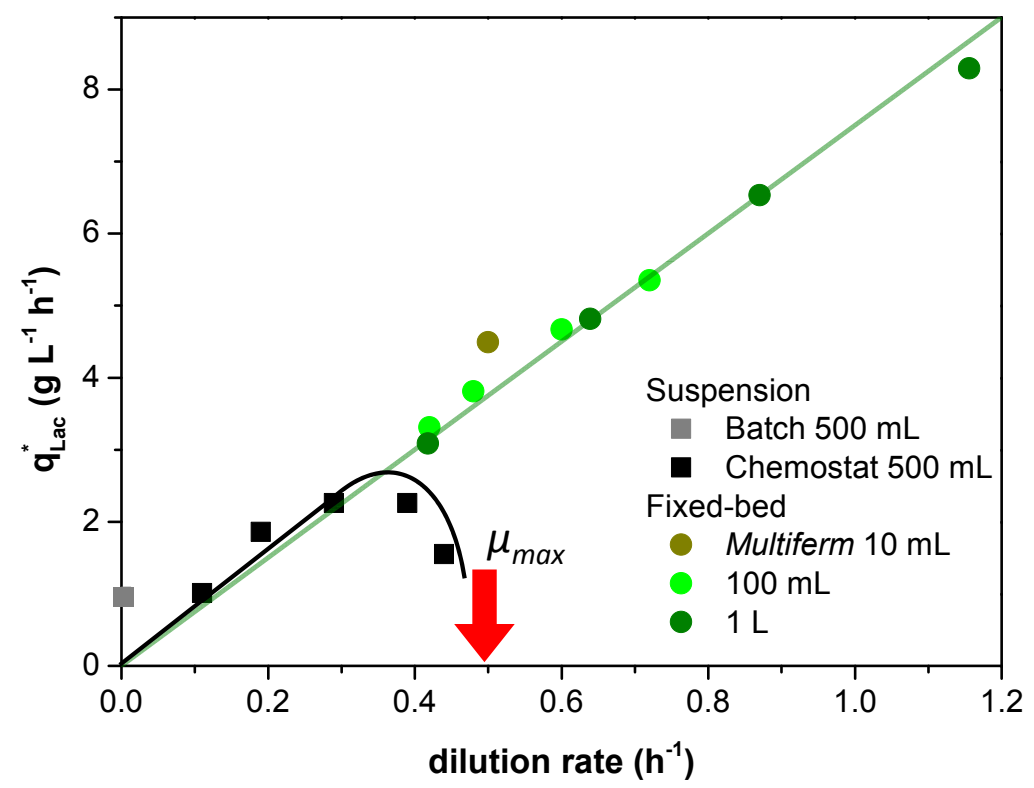

Fig. (6). Comparison of suspension and fixed-bed cultures for L. lactis. Volume specific lactate productivity $\boldsymbol{q}_{\text {Lac,FB }}^{*}$ versus dilution rate D. M17-Medium (Difco) with $5 \mathrm{~g} \mathrm{~L}^{-1}$ lactose, carrier: $10 \mathrm{~mL}$ Multiferm and $100 \mathrm{~mL}$ - VitraPOR ${ }^{\circledR} 4 \mathrm{~mm}, 1 \mathrm{~L}-\mathrm{VitraPOR}^{\circledR} 8 \mathrm{~mm}$. The arrow indicates the maximum specific growth rate of the strain.

For the fixed-bed-cultures, by definition a perfusion culture with cell retention, the productivity increased steadily with rising dilution rate. At low dilution rates (up to approx. $D=3 \mathrm{~h}^{-1}$ ) similar productivities were found as in chemostat cultures. But in contrast to the chemostat culture the productivity increased further with increasing dilution rate. Up to the highest dilution rate applied here $\left(D=1.16 \mathrm{~h}^{-1}\right.$, corresponding to $\left.2.4 \cdot \mu_{\max }\right)$ the curve did not flatten. The highest value determined here is approx. three times higher than the maximum in chemostat cultivation. Obviously the maximum for fixed-bed cultures has not been reached so far. This is in accordance with own observations reported in [7]. All fixed-bed systems used here can be described by the same spline.

\section{CONCLUSION}

The goal of the study was to evaluate the performance of fixed-bed bioreactor systems on different scales compared to the suspension culture. For this data for different suspension and fixed-bed reactors obtained with one specific strain cultivated in the same medium were used. The suggested concept for the development of fixed-bed processes could be 
confirmed. The first step, the multi-fixed-bed bioreactor Multiferm, provides an ideal downscaled and economical system that can be used for basic studies with low demands on equipment, medium, cells and labor. The next step, a 100 $\mathrm{mL}$ fixed-bed system provides data on the performance and long-term-stability of the culture. Problems that might not have been shown up in the Multiferm, e.g. insufficient long-term stability, can be detected here. The next further step, the $1 \mathrm{~L}$ fixed-bed, can be regarded as pilot scale already, as for the highest dilution rate applied here the medium throughput was already at $27.6 \mathrm{~L}$ per day. Even higher dilutions rates seem to be possible [7]. It is important to highlight that the data for all three fixed bed scales could be described by the same spline. This is very important with respect to scale-up, as obviously data from small scale systems can be used to predict the performance on a larger scale (for more details on scale-up see [7]).

As expected, fixed-bed bioreactors could be operated in a perfusion mode at a steady-state with dilution rates much higher than the maximum specific growth rate. Obviously the productivity in the fixed bed systems had not yet reached the maximum value. Therefore, a very high volume specific lactate productivity can be reached and maintained for long periods of time [7]. Especially long-term stability is the main premise for acceptance of continuous cultures on industrial scale. Alternative perfusion systems, mainly suspension cultures coupled with cell retention devises (e.g. filtration units) show significant limitations in this respect.

The fixed-bed process with lactic acid bacteria on macroporous carriers could be transferred to pilot scale without loss in productivity. The radial-flow bed geometry offers a further scale-up of the fixed-bed concept. Fixed-bed units with a radius in the range of the 1 L-reactor applied here can be extended in length. Several units can be operated in parallel. In conclusion, a process development tool for fixed-bed processes is now at hand that will pave the way for an industrial application of this promising technology.

\section{CONFLICT OF INTEREST}

The authors confirm that this article content has no conflict of interest.

\section{ACKNOWLEDGEMENTS}

The financial support from Federal Ministry of Education and Research (BMBF) under grant No. 0.31A124A ("ProTool 2") is gratefully acknowledged just as the work of the project partners (Ingenieurbüro Dr.-Ing. Schoop, medorex e.K. and Prof. Dr.-Ing. Volker C. Hass from Hochschule Furtwangen). The project was part of the BMBF BIOKATALYSE2021 cluster.

\section{REFERENCES}

[1] Mayo B, Aleksandrzak-Piekarczyk T, Fernndez M, et al. Biotechnology of lactic acid bacteria: Novel applications. In: Mozzi F, Raya RR, Vignolo GM, Eds. Updates in the metabolism of lactic acid bacteria. New Jersey: Wiley-Blackwell 2010; pp. 3-33.

[2] Starr JN, Westhoff G. Lactic acid. In: Ullmann's Encyclopedia of Industrial Chemistry. Weinheim: Wiley-VCH 2014; pp. 1-8. [http://dx.doi.org/10.1002/14356007.a15_097.pub3]

[3] Wee YJ, Kim JN, Ryu HW. Biotechnological production of lactic acid and its recent applications. Food Technol Biotechnol 2006; 44(2): 163-72.

[4] Zhang Y, Cong W, Shi S. Application of a pH feedback-controlled substrate feeding method in lactic acid production. Appl Biochem Biotechnol 2010; 162(8): 2149-56.

[http://dx.doi.org/10.1007/s12010-010-8989-x] [PMID: 20503104]

[5] Bai DM, Wei Q, Yan ZH, Zhao XM, Li XG, Xu SM. Fed-batch fermentation of Lactobacillus lactis for hyper-production of L-lactic acid. Biotechnol Lett 2003; 25(21): 1833-5. [http://dx.doi.org/10.1023/A:1026276925649] [PMID: 14677707]

[6] Ding S, Tan T. L-lactic acid production by Lactobacillus casei fermentation using different fed-batch feeding strategies. Process Biochem 2006; 41: 1451-4.

[http://dx.doi.org/10.1016/j.procbio.2006.01.014]

[7] Pörtner R, Faschian R, Goelling D. Fermentation of lactic acid bacteria: state of the art and new perspectives. In: Hilterhaus L, Liese A, Kettling U, Antranikian G, Eds. Applied biocatalysis: From fundamental science to industrial applications. Weinheim: Wiley-VCH 2016; pp. 314-42.

[http://dx.doi.org/10.1002/9783527677122.ch14]

[8] Doleyres Y, Fliss I, Lacroix C. Continuous production of mixed lactic starters containing probiotics using immobilized cell technology. Biotechnol Prog 2004; 20(1): 145-50.

[http://dx.doi.org/10.1021/bp020096w] [PMID: 14763837] 
[9] Lacroix C, Yildirim S. Fermentation technologies for the production of probiotics with high viability and functionality. Curr Opin Biotechnol 2007; 18(2): 176-83.

[http://dx.doi.org/10.1016/j.copbio.2007.02.002] [PMID: 17336510]

[10] Dagher SF, Ragout AL, Siñeriz F, Bruno-Bárcena JM. Cell immobilization for production of lactic acid biofilms do it naturally. Adv Appl Microbiol 2010; 71: 113-48. [http://dx.doi.org/10.1016/S0065-2164(10)71005-4] [PMID: 20378053]

[11] Lacroix C, Grattepanche F, Doleyres Y, Bergmaier D. Immobilised cell technologies for the dairy industry. In: Nedović V, Willaert R, Eds. Focus on biotechnology, 8B, applications of cell immobilisation biotechnology. Netherland: Springer 2005; pp. 295-319. [http://dx.doi.org/10.1007/1-4020-3363-X_18]

[12] Tango MS, Ghaly AE. A continuous lactic acid production system using an immobilized packed bed of Lactobacillus helveticus. Appl Microbiol Biotechnol 2002; 58(6): 712-20. [http://dx.doi.org/10.1007/s00253-002-0970-3] [PMID: 12021789]

[13] Pörtner R, Seemuk M, Schlothauer RC, Elsser D. Anaerobe Kultivierung von Lactococcus lactis im Festbettreaktor. Chem Ing Tech 2004; 76(10): 1599-602. [http://dx.doi.org/10.1002/cite.200407012]

[14] Roble ND, Ogbonna JC, Tanaka H. L-Lactic acid production from raw cassava starch in a circulating loop bioreactor with cells immobilized in loofa (Luffa cylindrica). Biotechnol Lett 2003; 25(13): 1093-8. [http://dx.doi.org/10.1023/A:1024192131343] [PMID: 12889820]

[15] Lamboley L, Lacroix C, Artignan JM, Champagne CP, Vuillemard JC. Long-term mechanical and biological stability of an immobilized cell reactor for continuous mixed-strain mesophilic lactic starter production in whey permeate. Biotechnol Prog 1999; 15(4): 646-54. [http://dx.doi.org/10.1021/bp990063p] [PMID: 10441356]

[16] Chantawongvuti R, Veerajetbodithat J, Jaturapiree P, Muangnapoh C. Immobilization of Lactobacillus salivarius ATCC 11741 on loofa sponge coated with chitosan for lactic acid fermentation. J Microbiol Biotechnol 2010; 20(1): 110-6. [PMID: 20134241]

[17] Faschian R, De S, Pörtner R. Multi-fixed-bed bioreactor system applied for bioprocess development of immobilized lactic acid bacteria. Open Biotechnol J 2016; 10: 1-9. [http://dx.doi.org/10.2174/1874070701610010001]

[18] Fassnacht D, Pörtner R. Experimental and theoretical considerations on oxygen supply for animal cell growth in fixed-bed reactors. J Biotechnol 1999; 72(3): 169-84. [http://dx.doi.org/10.1016/S0168-1656(99)00129-7] [PMID: 10443023]

[19] Pörtner R, Platas OB, Fassnacht D, Nehring D, Czermak P, Märkl H. Fixed-bed reactors for the cultivation of mammalian cells: design, performance and scale-up. Open Biotechnol J 2007; 1: 41-6. [http://dx.doi.org/10.2174/1874070700701010041]

[20] Faschian R, Minden S, Pörtner R. Experimental investigation and reaction kinetics modeling of biomass formation, substrate consumption and product formation during start-up of fixed-bed cultures with immobilized Lactococcus lactis ssp. lactis. J Bioprocess Biotech 2016; 6: 294. [http://dx.doi.org/10.4172/2155-9821.1000294]

(C) 2017 Faschian et al.

This is an open access article distributed under the terms of the Creative Commons Attribution 4.0 International Public License (CC-BY 4.0), a copy of which is available at: (https://creativecommons.org/licenses/by/4.0/legalcode). This license permits unrestricted use, distribution, and reproduction in any medium, provided the original author and source are credited. 